\title{
Career Choices of Students in Senior High Schools in Ghana
}

\author{
Samuel Smith Esseh ${ }^{1,2}$ Lucy Afeafa Ry-Kottoh ${ }^{2 *}$ Solomon Kwesi Owusu ${ }^{2}$ \\ 1. Public Knowledge Project, Canada (Associate). \\ 2. Kwame Nkrumah University of Science and Technology, Kumasi, Ghana \\ *E-mail of the corresponding author: lary-kottoh.cass@knust.edu.gh
}

\begin{abstract}
Deciding on the educational path to pursue to arrive at one's preferred career destination is important. Based on a survey that adapted Germeijs and Verschueren's (2006) Study Choice Task Inventory (SCTI) to gather relevant data from 1,006 senior high school student respondents, this research assesses the decisional process of how senior high school students choose programmes of study in higher institutions and explores the career guidance and counselling services senior high schools in Ghana provide for their students. Our findings showed that high school students in Ghana were well-oriented about the study choice task and quite decided about the programmes of study to pursue in higher education. The study also found that senior high schools lack the career guidance and counselling infrastructure needed to support students in their efforts to make informed educational career decisions. Also, to a large extent, students relied on themselves for information as they consider the options available in their choices of programmes to study in higher education.
\end{abstract}

Keywords: Career choice, high school students, Ghana, guidance and counselling, decisional tasks

DOI: $10.7176 / \mathrm{JEP} / 12-10-10$

Publication date: April $30^{\text {th }} 2021$

\section{Introduction}

Career choice options have become broad and at one point, students will face the challenge of deciding about this important aspect of their upward progression on the academic and professional ladder. Many factors influence the career choices students make: personality traits; elements in the environment; opportunities and experiences (Borchert, 2002). The senior high school level is a point in the Ghanaian education system where critical decisions are made to pursue further studies towards the realisation of a chosen profession or career. Making decisions at this point about the choice of programmes and institutions in which to pursue the programme of choice all form part of career planning and decision making.

Kidd (2006) observed that providing adequate information to individuals at the right time usually makes a big difference in their career planning. This knowledge goes beyond mere awareness but includes gaining a deep understanding of distinctive character and personality traits and how that relates to career preferences. It also includes understanding the processes involved in making such decisions and the various array of career options available to make informed decisions.

However, studies have shown that students finish their high school education without enough knowledge on career choices due to a lack of career guidance and counselling (Puja, 2001; Mvungi, 2009). This assertion is further supported by Avugla (2011) that most students in Ghana complete their senior high school education without adequate knowledge on career choices. Otuei (2017) also concluded that many students in senior high school face difficulties relating to inconsistent information because of internal conflicts. As a result, many students choose careers that may not suit their personalities, based on vague knowledge and/or preconceived perceptions about the various programs of study offered in tertiary institutions. Hence, they are directly or indirectly affected when they start tertiary education (Woasey, 2015). Germeijs and Verschueren (2006) suggest that poor implementation of study choice could increase the risk of dropout. This inadequate knowledge about career choices limits students' ability to make proper career decisions and can affect their commitment, academic adjustment, performance and actualization in the programmes they study.

Considering that the outcome of this decision has a big influence on the essence of who students will turn out to become in later life, they must do so from a point of knowledge. It is therefore very important to put in place certain structures and systems that will help prepare students to be in a better position to make career decisions out of knowledge. It is also necessary that in doing this, structures that have been put in place to guide students in the senior high schools to make informed decisions regarding their careers should also be analysed. 


\subsection{Justification of the Study}

Literature on career choices in Ghana has largely emphasised career choice decisions among students in the tertiary institutions (Zotorvie, 2016; Dokosi, 2014; Woasey, 2015; Fabea, 2014; Ayiah-Mensah, Mettle \& Ayimah, 2014; Danquah, 2012). Other studies that sought to analyse career choice decisions among senior high school students were Otuei (2017) and Lawer (2015). This makes research that explores all the dimensions of career decision-making phenomena by students in Ghana inadequate. Our study, therefore, fills the gap and adds to the existing literature available in this field of knowledge in Ghana.

Again, whereas Lawer (2015) concluded that the majority of students were pursuing their desired choices of programmes of study in senior high school, Otuei (2017) postulates that, among other things, senior high school students face a knowledge challenge with regards to making career choices moving on from that level. Given that there is no knowledge about the career decisions students make as they transition from senior high school, this research is justified to fill this knowledge gap.

There is scanty career decision-making literature that focuses explicitly on choosing programmes of study in higher education. Current models or instruments either assess the choice of jobs like the Career Exploration Survey [CES], developed by Stumpf et al., (1983); Vocational Exploration and Commitment Scale [VECS] by Blustein, Ellis, et al., (1989) and Assessment of Career Decision Making [ACDM] and Buck \& Daniels (1985), or combine items on choosing a job and choosing a study all in one scale.

The Study Choice Task Inventory (SCTI) scale, developed by Veerle Germeijs and Karine Verschueren (2006) assesses adolescents' decisional process of choosing studies in higher education. We adapted the SCTI instrument into a questionnaire, to gather data on the decisional process of choosing a programme of study in higher education by senior high school students in Ghana as we found the SCTI scale a suitable instrument fit for our study.

\subsection{Objectives of the Study}

1. To assess the decisional process of choosing a programme of study in higher education among senior high school students in Ghana.

2. To explore the career guidance and counselling services senior high schools provide for their students.

\subsection{Significance of the Study}

This paper brings to the fore pertinent issues that can help address the gap between students' career interests and the variety of tertiary institutions available to them and the programmes they offer. The study would also inform stakeholders of career guidance and ultimately influence the structure of career counselling programs in senior high schools to enable them to meet specific student needs in career choice decision making. The research will serve as reference material for future research studies on career decision making at the senior high school level in Ghana.

\section{Review of relevant literature}

The attempt to describe precisely what a career is has led scholars to explore the many facets that characterise the topic. Sociologists have been interested in career choices and development because of its repercussion on socioeconomic inequality and mobility as occupation strongly determines status, earnings, wealth and lifestyle (Johnson and Mortimer, 2002). In addressing individuals' professional affiliations, Zunker (1990) defined career as "the activities and positions involved in vocations, occupations, and jobs and related activities associated with an individual's lifetime of work" (p. 3). The most relevant definition of career to this study is one that defines a career as a job or profession that one is trained for and undertakes (Avugla, 2011; Woasey, 2015), This definition takes cognizance of the need for training towards arriving at a specific career destination. This suggests that the entire process of making choices of what to do while schooling all form part of career decision making.

As Woasey (2015) states, choosing a profession that aligns with personal and external factors is only one side of the entire career decision-making process. Of more importance perhaps is deciding about the educational path to follow to arrive at one's destination. Higher education usually ushers one directly into their chosen professional career, and deciding on the programme to study in higher education is probably the biggest decision an individual will make in their onward progression in the academic career path. Access to financial resources also plays a key role in career choice. Discussing determinants of career choice, Carner and Oketen (2010) assert that risk preference is important in making career choices, as risk aversion is based on access to financial resources and family income, the self-employment status of fathers, social security status were important in choosing a 
major in colleges in Turkey (p. 1074).

According to Super's career model, individuals' career preferences are influenced by their experiences as they progress through various stages of life. The second stage (exploration stage and is usually from age 15 to 24) is where they try many things through lessons at school, work experience, hobbies, tentative choice and skill development dissonance (Super, 1980; Dokosi, 2014).

In the Ghanaian educational system, students in senior high school (SHS) fall within this age bracket. And while they are still exploring and trying out different things, it is expected that they make decisions that will set them up on the path of career fulfilment, especially regarding choosing a programme of study for tertiary education. This position is also supported by Germeijs and Verschueren (2006) who maintain that it is during this period that adolescents make their first career-related decisions.

At this stage, the most influencing factors on an individual's career preference usually are career suited for personality, environment/background, interests, values and goals (Super, 1957). This position seems to agree with that of Borchert (2002) who postulate that the influencing factors of career decision making are personality traits, elements in the environment, and opportunities and experiences. However, Dokosi (2014) asserts that these variables are subject to change over time as individuals continue to develop. These variables are deemed important, and this study assesses the extent to which these important variables influence the choice of a programme of study made by SHS students in Ghana.

Of equal importance in making informed career-related decisions is the role of career guidance and counselling in schools. It presents students with vital information about educational and training options available, programmes in higher education related to students' present courses of study and the requirements of wellsuiting programmes (Lawer, 2015). This information, when made available to students, enables them to select fields of study, and consequently appropriate careers.

\subsection{Conceptual Framework}

This study examines the decision-making process senior high school students go through in selecting their choice of programmes for higher education. This is done by assessing the various tasks that students complete in their upward progression in the decision-making process. This concept of completing decisional tasks was put forward by Germeijs and Verschueren (2006). They theorised six central career decisional tasks students would have to complete before choosing a programme of study in higher education. These tasks are Orientation to choice, Selfexploration, Broad Exploration of the Environment, In-depth Exploration of the Environment, Decision Making and Commitment. Figure 1 represents the concept behind the study.

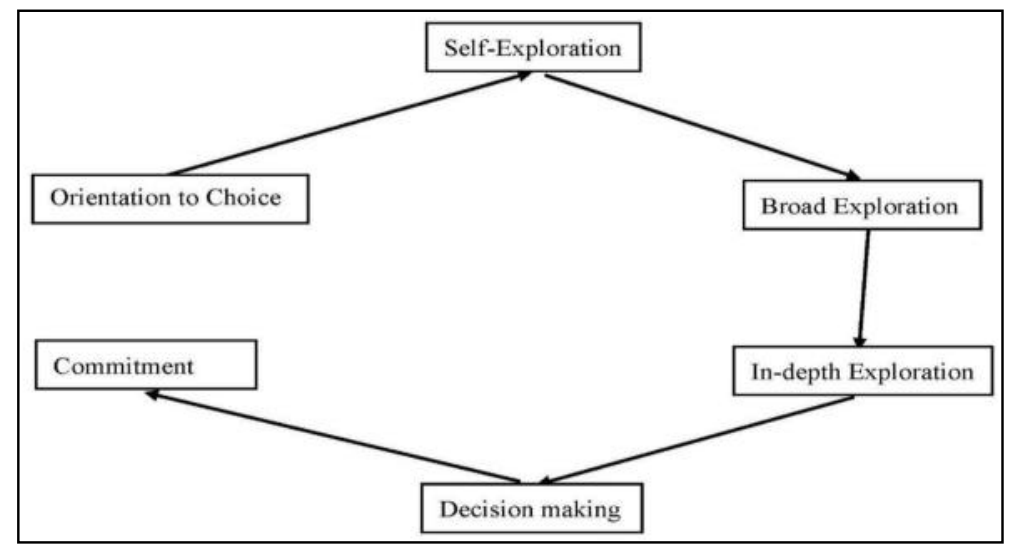

Conceptual framework

Figure 1: Tasks in the career decision-making process

\section{Methodology}

\subsection{Population and Sampling Techniques}

The target population for the study included final year students in selected senior high schools in the Greater Accra and Ashanti Region in Ghana. These regions were chosen because they are cosmopolitan, had 
multicultural students from all parts of the country with varied socio-economic backgrounds that can influence the career choices they make.

A stratified cluster sampling technique was used to group schools within the Regions into categories A, B and C, based on the Ghana Education Service Register (2015). Schools classified under Category A had students' whose academic performance is predominantly above average, Category B schools predominantly average, and Category $\mathrm{C}$ schools predominantly below average. It is necessary to consider this categorisation because of the difference in the academic abilities of students across the various categories which may influence the career decisions they make.

Within each category of schools, the purposive sampling technique was used to select schools comprising coeducational schools (Mixed), all-female schools (Girls only) and/or all-male schools (Boys only) in Greater Accra and Ashanti Regions. This approach was adopted to ensure a fair representation of all genders within the sample because of the possibility of the gender type of the school influencing students' career decision making.

After sampling, eighteen (18) senior high schools were selected from both regions, but data could only be collected from seventeen (17) schools because of authorisation difficulties. Of the seventeen (17), nine (9) schools were from Greater Accra Region and eight (8) from Ashanti Region, nine (9) mixed-gender schools, five (5) all-girls schools and three (3) all-boys schools.

\subsection{Respondents}

Presented in the table below are the details of the selected schools and the number of their final year students surveyed. The aggregate number of final year students for all the schools $(12,352)$ forms the population of the study. To ensure a concise and workable sample size for the study, sample size calculations were made on the aggregate number of final year students per category and the result spread across the schools within the category. The sample size was determined using Taro Yamane's formula for calculating sample size. The formula is thus:

$$
\mathrm{n}=\frac{N}{1+N(e)^{2}} \text { where } \mathrm{n}=\text { sample size; } \mathrm{N}=\text { population, } \mathrm{e}=\text { margin of error at } 5 \%(0.05)
$$

\subsection{Data Collection}

The research used a questionnaire adapted from the Study Choice Task Inventory (SCTI) scale developed by Veerle Germeijs and Karine Verschueren (2006) to measure six career decisional tasks: orientation to choice, self-exploratory behaviour, broad exploratory behaviour, in-depth exploratory behaviour of the environment, decisional status and commitment. These six scales are explained below:

1. Orientation to choice comprises twelve items, six assessing students' level of awareness and their need to decide, and the other six how motivated they are to decide on their career paths/progression. These two variables combined will determine how much-oriented students are to choosing a programme to study in higher education. For each variable, we constructed three positive and three negative statements to measure students' level of awareness and motivation.

2. Self-Exploratory Behaviour comprises twenty items that combine four elements of self-exploration (skills, interests, values, and approach to study) and five important sources of information (self, parents, friends, teachers, and others).

3. The Broad Exploratory Behaviour scale contains five items that seek to find out the attempt students have made to obtain information about career alternatives.

4. In-Depth Exploratory Behaviour of the Environment probes the behaviour of students as they were asked which programmes, they had information on. Also, ten items were included to find out how much they explored in their quest to find information specifically about their programmes of choice.

5. Decisional status ascertains if students had already decided on a programme of study in a higher institution.

6. Commitment scale rates students' level of commitment to the programmes they have decided on based on eight items. 
Table 1: Selected schools, their sample sizes and their response rate

\begin{tabular}{|c|c|c|c|c|c|}
\hline & Gender & Region & Population & Sample & Response \\
\hline \multicolumn{6}{|l|}{ CATEGORYA } \\
\hline 1. Accra Academy Senior High School & Boys & G. Accra & 889 & 62 & 55 \\
\hline 2. Accra Girl's Senior High & Girls & G. Accra & 572 & 62 & 66 \\
\hline 3. Achimota Senior High School & Mixed & G. Accra & 1,060 & 62 & 55 \\
\hline 4. Kumasi Anglican School & Mixed & Ashanti & 841 & 62 & 66 \\
\hline 5. Yaa Asantewaa Senior High & Girls & Ashanti & 1,040 & 62 & 57 \\
\hline 6. TI Amass Senior High School & Mixed & Ashanti & 1,250 & 63 & 60 \\
\hline & & & 5,652 & 373 & 359 \\
\hline \multicolumn{6}{|l|}{ CATEGORY B } \\
\hline 7. St. Thomas Aquinas Senior High School & Boys & G. Accra & 663 & 62 & 67 \\
\hline 8. Wesley Grammar Senior High School & Mixed & G. Accra & 895 & 62 & 54 \\
\hline 9. Ebenezer Senior High School & Mixed & G. Accra & 575 & 61 & 63 \\
\hline 10. Kumasi Wesley Girls School & Girls & Ashanti & 862 & 62 & 62 \\
\hline 11. Osei Tutu Senior High & Boys & Ashanti & 1,293 & 62 & 60 \\
\hline 12. KNUST Senior High School & Mixed & Ashanti & 841 & 62 & 58 \\
\hline & & & 5,129 & 371 & 364 \\
\hline \multicolumn{6}{|l|}{ CATEGORYC } \\
\hline 13. Accra Wesley Girls Senior High School & Girls & G. Accra & 458 & 64 & 56 \\
\hline 14. Kaneshie Senior Technical School & Mixed & G. Accra & 365 & 64 & 55 \\
\hline 15. Holy Trinity Cathedral School & Mixed & G. Accra & 410 & 64 & 58 \\
\hline 16. St. Mary's Girls School & Girls & Ashanti & 136 & 63 & 57 \\
\hline 17. Islamic Senior High School & Mixed & Ashanti & 202 & 63 & 57 \\
\hline & 1,571 & 318 & 283 \\
\hline \multicolumn{3}{|l|}{ Total } & 12,352 & 1,062 & 1,006 \\
\hline
\end{tabular}

\subsection{Reliability and Validity}

We performed a Cronbach's alpha test on our data collection instrument (the SCTI scale) and got indices that ranged between .71 and .90, showing they were between acceptable and very good consistency (Devillis, 1991). A confirmatory factor analysis (CFA) performed to evaluate the internal structure of the scales, confirmed the expected internal structure of the SCTI. All loadings on the respective latent factors were significant (with standardised factor loadings ranging between .56 and .91).

\section{Results and Discussions}

\subsection{Demographic information of respondents}

Respondents were students in the final year, sampled from all the major courses offered: General Science, General Arts, Visual Arts, Home Economics and Business in senior high schools in Ghana and across the three categories (A, B, C) as classified by the Ghana Education Service (GES). A total of 1006 students from 17 schools responded to the questionnaire. Responses from four schools (two in category A and two in category B) exceeded the sample, indicating the respondents were motivated and interested in the study. The response rate was 94.5\%. The modal age of a final year student in SHS in Ghana is from 18 to 20. 
Table 2: Demographic information of respondents

\begin{tabular}{|c|c|c|c|}
\hline Demographic & & $\mathbf{N}$ & Per cent \\
\hline Gender of student & $\begin{array}{l}\text { Male } \\
\text { Female }\end{array}$ & $\begin{array}{l}393 \\
613\end{array}$ & $\begin{array}{l}39.1 \\
60.9\end{array}$ \\
\hline Age & $\begin{array}{l}12-14 \\
15-17 \\
18-20 \\
21 \text { and above }\end{array}$ & $\begin{array}{c}6 \\
396 \\
589 \\
12\end{array}$ & $\begin{array}{c}0.6 \\
39.4 \\
58.5 \\
1.2\end{array}$ \\
\hline Course of study & $\begin{array}{l}\text { Science } \\
\text { General Arts } \\
\text { Business } \\
\text { Visual Arts } \\
\text { Agricultural Science } \\
\text { Home Economics }\end{array}$ & $\begin{array}{l}315 \\
418 \\
133 \\
40 \\
36 \\
55\end{array}$ & $\begin{array}{l}31.3 \\
41.6 \\
13.2 \\
4.0 \\
3.6 \\
5.5\end{array}$ \\
\hline Category of schools & $\begin{array}{l}\text { Category A } \\
\text { Category B } \\
\text { Category C }\end{array}$ & $\begin{array}{l}359 \\
364 \\
283\end{array}$ & $\begin{array}{l}35.7 \\
36.2 \\
28.1\end{array}$ \\
\hline
\end{tabular}

\subsection{Orientation to choice}

To measure students' level of awareness and motivation to choice, respondents were asked to score each statement on a scale of 1 to 9 , with 1 meaning 'not at all applicable' and 9 meaning 'entirely applicable'. Mean marks were then calculated as a measure of central tendency.

Table 3: Students' awareness and motivation to choice levels

\begin{tabular}{|c|c|c|}
\hline Awareness & $\mathbf{N}$ & Mean \\
\hline I am worried about my choice of programme. ${ }^{a}$ & 997 & 5.29 \\
\hline The thought that I have to choose a programme occurs to me often. ${ }^{a}$ & 995 & 6.25 \\
\hline At the moment, I often think about what I am going to study. ${ }^{a}$ & 993 & 4.28 \\
\hline I often daydream about what it will be like to be in higher education. & 987 & 7.33 \\
\hline I often daydream about which programme I will choose. & 983 & 6.42 \\
\hline I often think about the fact that I have to choose a programme. & 985 & 6.74 \\
\hline Total Awareness Level (Mean) & 1006 & 6.0483 \\
\hline \multicolumn{3}{|l|}{ Motivation } \\
\hline $\begin{array}{l}\text { I know I will have to choose a programme, and I am motivated to think about this } \\
\text { decision at the moment. }{ }^{\text {a }}\end{array}$ & 999 & 6.02 \\
\hline It takes no effort for me to already think about my choice of a programme. ${ }^{a}$ & 990 & 5.87 \\
\hline I feel like thinking already about what to study. ${ }^{\text {a }}$ & 998 & 6.81 \\
\hline
\end{tabular}




\begin{tabular}{|l|c|c|}
\hline I am willing to spend time looking into programme choices at the moment. & 984 & 6.87 \\
\hline I am motivated to tackle choosing a programme at the moment. & 981 & 6.29 \\
\hline I am willing to make an effort now to choose the right programme. & 989 & 7.63 \\
\hline Total Motivation Level (Mean) & $\mathbf{1 0 0 6}$ & $\mathbf{6 . 5 7 2 9}$ \\
\hline
\end{tabular}

a These statements are reversed versions of the original statements; from negative to positive.

On this scale of 1 to 9 , the total awareness level stands at 6.0483, which indicates a slightly applicable agreement to the six (6) statements of awareness. Similarly, the total motivation level also stands at 6.5729 , a moderately applicable response to the six (6) statements of motivation among respondents. This result reveals that Ghanaian Senior High School students are largely aware of the task to choose a programme for higher education because more often than not, they "often daydream about what it will be like to be in higher education" (7.33). This knowledge translates into a motivational force for them to be "willing to make an effort now to choose the right programme" (7.63). Putting these two dimensions together, we infer that Ghanaian SHS students seem to be well oriented to choosing what programme to study in higher education.

\subsection{Thinking about yourself}

Personal and external factors play a very important role in helping to shape the essence of who an individual is. Respondents were therefore asked to show how much time they spent thinking about four dimensions of their characteristics: their skills, interests, values and approach to study. A part of this assessment concerns determining how involved some members of their external environment are, as they assess these characteristics. The study choice task is the second in the decisional process students go through in choosing what programme to study in higher education.

Table 4: Self-exploratory behaviour of students

\begin{tabular}{|l|c|c|c|c|c|c|c|c|c|}
\hline \multirow{2}{*}{} & \multicolumn{2}{|c|}{ Skill } & \multicolumn{2}{c|}{ Interest } & \multicolumn{2}{c|}{ Values } & \multicolumn{2}{c|}{$\begin{array}{c}\text { Approach to } \\
\text { study }\end{array}$} & $\begin{array}{c}\text { TOTA } \\
\text { L }\end{array}$ \\
\cline { 2 - 10 } & $\mathbf{N}$ & Mean & N & Mean & N & Mean & N & Mean & Mean \\
\hline Self & 994 & 2.53 & 998 & 2.49 & 99 & 2.52 & 100 & 2.73 & $\mathbf{2 . 5 6 6 4}$ \\
& & & & & 7 & & 4 & & \\
\hline Parents & 100 & 2.02 & 100 & 2.19 & 99 & 2.07 & 100 & 1.95 & $\mathbf{2 . 0 5 8 5}$ \\
& 0 & & 2 & & 9 & & 2 & & \\
\hline Friends & 995 & 2.10 & 996 & 2.15 & 99 & 2.07 & 100 & 2.19 & $\mathbf{2 . 1 2 5 0}$ \\
& & & & & 4 & & 2 & & \\
\hline Teachers & 985 & 1.64 & 992 & 1.59 & 99 & 1.53 & 994 & 1.77 & $\mathbf{1 . 6 3 6 9}$ \\
& & & & & 0 & & & & \\
\hline $\begin{array}{l}\text { Other } \\
\text { people }\end{array}$ & 995 & 1.95 & 997 & 1.97 & 99 & 1.93 & 100 & 1.87 & $\mathbf{1 . 9 3 2 4}$ \\
\hline
\end{tabular}

This assessment was done on a scale of 1 to 3; 1 representing 'never' and 3 representing 'often'. Results, presented in the table above, show that students more often reflect on their characteristics for themselves (2.5664) than they speak about those characteristics to the immediate people around them (parents, friends, teachers and other people). This implies that apart from self, the single most influencing member of students' external environment who directly impact their career choices are friends (2.1250). Parents (2.0585) follow closely and then come other people (1.9324) and teachers (1.6369). It is especially worth noting that again, contrary to expectations, students spoke less with their teachers (1.77) about their approach to study but prefer speaking to friends (2.19) more. The minimal influence of teachers on students' choice as indicated in the ranking list of people they talk to is quite worrying, seeing that teachers should be in a better position to assist students to make the right career-related choices.

\subsection{Broad exploratory behaviour of the environment}

After reflecting on their characteristics, respondents were asked to indicate on a scale of 1 to 3 (1 representing 'never' and 3 representing 'often') the extent to which they look up information on programmes in higher education. 
Table 5: Broad exploratory behaviour of the environment

\begin{tabular}{|l|c|c|}
\hline & N & Mean \\
\hline General overviews about the structure of higher education & 999 & 2.34 \\
\hline Brochures of different programmes & 996 & 2.10 \\
\hline Overviews of programme course content & 998 & 2.21 \\
\hline Overviews of programme titles & 997 & 2.12 \\
\hline Overviews of education institution addresses & 998 & 1.99 \\
\hline
\end{tabular}

Results from the table above show that students have sometimes too often taken some initiative to find out information about higher education. From looking at 'general overviews about the structure of higher education' (2.34) to reviewing 'overviews of education institution addresses' (1.99), students have sometimes taken the initiative on their own.

Having explored broadly about higher education and programmes, respondents were asked to show the number of programmes for which they have made specific enquiries or reviewed. We present frequencies of this in the table below.

Table 6: Number of programmes specifically reviewed

\begin{tabular}{|l|c|c|c|}
\hline & Freq. & $\begin{array}{c}\text { Per } \\
\text { cent }\end{array}$ & $\begin{array}{c}\text { Valid } \\
\text { Percent }\end{array}$ \\
\hline I have not looked up any information yet & 163 & 16.2 & 16.3 \\
\hline About one specific programme & 243 & 24.2 & 24.3 \\
\hline About 2 to 5 programmes & 519 & 51.6 & 52.0 \\
\hline About 6 to 10 programmes & 44 & 4.4 & 4.4 \\
\hline About more than 10 programmes & 29 & 2.9 & 2.9 \\
\hline Total & $\mathbf{9 9 8}$ & $\mathbf{9 9 . 2}$ & $\mathbf{1 0 0 . 0}$ \\
\hline Missing System & 8 & 0.8 & \\
\hline Total & 1006 & 100.0 & \\
\hline
\end{tabular}

Results show that more than half of respondents $(519 ; 51.6 \%)$ have checked out specific information about 2 to 5 programmes of study in higher education. An additional 243 respondents $(24.2 \%)$ have looked up information about one specific programme. This statistic gives firm support to earlier findings in section 4.2 of this study that SHS students in Ghana are quite motivated and "willing to make an effort now to choose the right programme". That motivation translates into looking up specific information about some programmes as seen in the table above. However, of the 1006 respondents, 163 (16.2\%) have not looked up any information yet about any specific programme.

After finding specific information about several programmes, respondents were asked to score how often they have delved in-depth into finding out information about the programmes they have specific interests in and from where they get the information. This makes for the next decisional task in making an educational career choice. Mean scores were calculated on a 3-point scale where 1 means 'never' and 3 means 'often'. 
Table 7: In-depth exploratory behaviour of the environment

\begin{tabular}{|c|c|c|}
\hline & $\mathbf{N}$ & $\begin{array}{l}\text { Me } \\
\text { an }\end{array}$ \\
\hline Thoroughly read a brochure about a programme. & $\begin{array}{r}83 \\
2\end{array}$ & 2.20 \\
\hline Compared the brochures of different programmes. & $\begin{array}{r}83 \\
5\end{array}$ & 2.01 \\
\hline $\begin{array}{l}\text { Been to an information day at an educational institution where a programme is } \\
\text { offered. }\end{array}$ & $\begin{array}{r}82 \\
8\end{array}$ & 1.60 \\
\hline Made an overview of information I have found out about a particular programme. & $\begin{array}{r}83 \\
0\end{array}$ & 2.16 \\
\hline Talked to students in higher education about a programme. & $\begin{array}{r}83 \\
3\end{array}$ & 2.19 \\
\hline Looked at a coursebook of a particular programme. & $\begin{array}{r}83 \\
4\end{array}$ & 2.01 \\
\hline $\begin{array}{l}\text { Talked to people with professional experience about their studies and/or their } \\
\text { profession. }\end{array}$ & $\begin{array}{r}83 \\
0\end{array}$ & 1.98 \\
\hline Talked to my parents to find out more about a programme. & $\begin{array}{r}83 \\
7\end{array}$ & 2.00 \\
\hline Talked to a teacher to find out more about a programme. & $\begin{array}{r}83 \\
6 \\
\end{array}$ & 1.90 \\
\hline Talked to friends to find out more about a programme. & $\begin{array}{r}83 \\
6 \\
\end{array}$ & 2.11 \\
\hline
\end{tabular}

Among the highest consulted important sources of information on tertiary education-related programmes of study are career information materials (brochures; 2.20 and course books of particular programmes; 2.01). People who students sometimes talk to for such information include, in ranked order, students already in higher education (2.19), parents (2.00), people with professional experience (1.98) and teachers (1.90). Information day organised by education institutions (1.60) is the least source of information to students, possibly because it is not a prevalent practice among tertiary institutions in Ghana.

\subsection{Decisional Status}

With sufficient information about some programmes, respondents were asked to list the programmes they are actively considering and whether they have even settled on a first choice among the alternatives. Their responses were grouped under three categories to show their decisional status.

Table 8: Decisional Status of students

\begin{tabular}{|l|c|c|c|}
\hline & Freq. & Per cent & $\begin{array}{c}\text { Valid } \\
\text { Percent }\end{array}$ \\
\hline Alternatives listed with first choice & 826 & 82.1 & 82.1 \\
\hline Alternatives listed with no first choice & 74 & 7.4 & 7.4 \\
\hline No alternatives listed with no first choice & 106 & 10.5 & 10.5 \\
\hline Total & $\mathbf{1 0 0 6}$ & $\mathbf{1 0 0 . 0}$ & $\mathbf{1 0 0 . 0}$ \\
\hline
\end{tabular}

It is good to find that $82.1 \%$ of the 1006 respondents had alternatives they are considering, out of which they would decide which programme would be their first choice. Only 74 respondents have alternative programmes listed but were undecided about which one they would prefer as their first-choice programme. A further 106 $(10.5 \%)$ had neither any alternative listed nor a first-choice decision made. This brings the number of undecided respondents to $180(17.9 \%)$.

4.6 Commitment to choice

This is the last task that completes the decisional process of choosing a programme of study in higher education. 
Having chosen a programme to study in higher education, students are expected to stay committed to their choices. To measure how committed students are to their choices, respondents were presented with eight (8) statements, each measuring how certain respondents are to their choices. This assessment was done on a scale of 1 to 6,1 being 'definitely not/not at all' and 6 being 'yes very much/certainly'. Mean scores were calculated to determine the average levels of agreement to the statements.

Table 9: Students' level of commitment to choice

\begin{tabular}{|c|c|c|}
\hline & $\mathrm{N}$ & $\begin{array}{c}\text { Mea } \\
\mathrm{n}\end{array}$ \\
\hline I won't be able to easily change my mind about this programme. ${ }^{a}$ & 823 & 4.15 \\
\hline I am not uncertain about the programme. ${ }^{a}$ & 822 & 3.99 \\
\hline $\begin{array}{l}\text { This programme provides me with a feeling of optimism about and confidence in the } \\
\text { future. }\end{array}$ & 816 & 5.17 \\
\hline I won't just as well change my mind about the programme choice. ${ }^{a}$ & 820 & 4.07 \\
\hline I am certain about this programme. & 823 & 5.04 \\
\hline I will defend this programme when talking to people who don't agree. & 818 & 4.98 \\
\hline I am willing to face problems to achieve a degree in this programme. & 821 & 4.14 \\
\hline This programme is my choice entirely. & 824 & 5.19 \\
\hline Total commitment level & 824 & $\begin{array}{c}4.58 \\
84\end{array}$ \\
\hline
\end{tabular}

a These statements are reversed versions of the original statements; from negative statements to positive.

With the highest scale being 6, the aggregate level of commitment to choice as showed by respondents was 4.5884. This means that SHS students in Ghana are committed to their choices, even though many said the programme is their own choice entirely (5.19). Even more revealing is the fact that their programme choices provide respondents 'with a feeling of optimism about and confidence in the future' (5.17). Certainty of programme choice levels (5.04) was also quite high, and that lends support to the general commitment level of respondents.

\subsection{Career guidance and counselling in senior high schools in Ghana}

There must be a proper support system in place for guidance and counselling if adolescents are to make informed decisions about their educational career This could come in various forms; from structured guidance provided by career guides and counsellors to unstructured guidance provided by teachers, parents and friends. This part, therefore, asked respondents to indicate the form of career guidance and counselling service they encounter in their various schools by simply agreeing or disagreeing with the statements. This was done on a scale of 1 to 5 with 1 being strongly disagreed and 5 is strongly agreed.

To make the analysis simpler and understandable, the scale was reduced to 1 to 3,1 being disagreed, 2 being neutral and 3 being agreed. The data were recoded to merge responses for 'strongly disagree' and 'disagree' to be 1 and merge 'agree' and 'strongly agree' also to be 3. 
Table 10: Career Guidance and Counselling service in senior high schools

\begin{tabular}{|c|c|c|c|c|}
\hline Channels/Avenue & $\mathbf{N}$ & Disagree & Neutral & Agree \\
\hline Orientation programme in first year & 986 & 206 & 139 & 641 \\
\hline Days set aside to sensitise students about career choices & 988 & 273 & 167 & 548 \\
\hline School gatherings like morning assemblies & 987 & 466 & 194 & 327 \\
\hline Materials on educational career choices & 990 & 377 & 169 & 444 \\
\hline Teachers in the classrooms & 986 & 96 & 124 & 766 \\
\hline People talk about career. ${ }^{a}$ & 973 & 86 & 83 & 804 \\
\hline \multicolumn{5}{|l|}{ Personnel } \\
\hline Internal Career Counsellor & 990 & 522 & 122 & 346 \\
\hline Teachers & 988 & 329 & 136 & 523 \\
\hline External Career Counsellors & 992 & 120 & 95 & 777 \\
\hline I know who to ask. $^{\text {a }}$ & 986 & 445 & 150 & 391 \\
\hline \multicolumn{5}{|l|}{ Venue } \\
\hline The guidance and counselling office. & 976 & 473 & 113 & 390 \\
\hline The school's assembly hall. & 971 & 324 & 109 & 538 \\
\hline The classroom. & 967 & 238 & 182 & 547 \\
\hline The staff common room. & 962 & 685 & 110 & 167 \\
\hline \multicolumn{5}{|l|}{ Benefits of educational career guidance and counselling } \\
\hline $\begin{array}{l}\text { It has motivated me to find out more about tertiary } \\
\text { education. }\end{array}$ & 992 & 171 & 108 & 713 \\
\hline It has helped me reflect on my interests and skill-set. & 990 & 133 & 141 & 716 \\
\hline It has helped me in deciding on what programme to study. & 991 & 177 & 178 & 636 \\
\hline There is real benefit for me. ${ }^{a}$ & 989 & 217 & 115 & 657 \\
\hline
\end{tabular}

${ }^{a}$ These statements are reversed versions of the original statements; from negative statements to positive.

The dimensions of career guidance and counselling assessed are the avenues through which career information is passed on to students; the personnel available to carry out the service, and the various venues that career guidance and counselling are given/received. The study also found from students whether their schools' career guidance and counselling service has been of any real benefit to them in their efforts to make informed educational career decisions.

From the results, career information is often introduced to students from when they are in their first year in SHS through orientation programmes organised at arrival. This is clear as 641 respondents agreed with this statement. Another avenue that students received career information is through their teachers in their classrooms, seeing that 766 respondents agreed. 548 respondents also agreed that there are 'days set aside to sensitize students about career choices'. This, coupled with the fact that 444 students agreed they receive 'materials on educational career choices', means that senior high schools in Ghana make deliberate efforts to provide support to their students in their bid to select programmes in higher education. Respondents overwhelmingly agree (804) that there are talks of making career choices in the various schools.

Out of the three categories of personnel presented to respondents, internal career counsellors were the least consulted on choosing a programme of study in higher education. This could suggest the absence of dedicated career counsellors on the campuses of senior high schools in Ghana to deal with student issues. Their responsibilities have rather been taken over by teachers who 523 respondents agreed to provide them with career-related guidance. External career counsellors are also often invited by school authorities to offer the career counselling service to students.

Most respondents (473) disagree that there is no guidance and counselling office in their schools because, as has been established, there are no internal career counsellors to fill those offices. In its place, the school's assembly hall and the classrooms have become the venues to send and receive career-related information.

Respondents agree that educational career guidance and counselling has been of benefit to them in the areas of motivation to find out more about tertiary education (713), reflections on their personal characteristics (716) and making final decisions about choice of programme to study (636). 


\section{Conclusions}

Drawing on the literature and the findings from our study, this paper has established the real importance of exploring career options to make informed educational career decisions. Our assessment of the decisional process of choosing a programme of study in higher education among senior high school students in Ghana revealed that the students were generally well-oriented in making the decision about programmes to study in higher education. This is because they were largely aware of the task, to choose a programme for higher education, and were equally motivated to make the right choice.

Also, the participants' excellent knowledge about their personal characteristics equipped them to make choices of programmes and careers that suit their natural and gained capabilities. The study revealed that students reflected on their personal characteristics and explored broadly and specifically within their environment to gain information about the programmes they could choose in tertiary education. In terms of external influence as regards their choice, the students relied on friends, parents and teachers; with teachers scoring the least on the list of ranking, demonstrating the minimal influence teachers have on the students' career choice decisions, although they were reported to be giving career information in classrooms. In the light of this, it will of interest to investigate the role teachers play in career choices in future research to ascertain why students do not approach teachers for guidance in making career-related decisions.

This research also discovered that senior high school students were largely decided about a specific programme (their first choice) to pursue in higher education when they complete senior high school. Further, they were committed to their choices of programmes to study in higher education and will not easily change their minds about these choices. The study has also revealed that career guidance and counselling through orientation programmes and seminars took place sporadically in senior high schools. However, the infrastructure to support students to make effective career related decisions in senior high schools in Ghana was inadequate. This is reflected in the students' over-reliance on themselves and peers for information as they make very important considerations about their choices of what to study in higher education. In the light of this, it is prudent that stakeholders of education and career guidance and counselling formulate and implement policy to create guidance and counselling units in schools that lack them and equip those that have, to assist students to make informed career-related decisions.

\section{References}

Avugla, D. K. G., (2011). Factors influencing career choice among the senior high school students in the south Tongu District of Volta Region, Ghana. (Masters' Thesis). University of Education, Winneba.

Ayiah-Mensah, F., Mettle, F. O. \& Ayimah, J. K. C. (2014). Modelling the factors that influence career choice of technical and vocational students (a case study of Takoradi and Ho Polytechnics). International Journal of Mathematics and Statistics Studies. 2(5), 62-80.

Blustein, D. L., Ellis M. V. \& Devenis L. E. (1989). The development and validation of a two-dimensional model of the commitment to career choices process. Journal of Vocational Behavior. 35(3), 342-378

Borchert, M. (2002). Career choice factors of high school students: Masters' Thesis, Graduate College University of Wisconsin-Stout.

Buck, J. N., \& Daniels, M. G. (1985). Assessment of Career Decision Making (ACDM) manual. Los Angeles, CA: Western Psychological Services.

Caner, A. \& Okten, C. (2010). Risk and Career Choice: Evidence from Turkey. Economics of Education Review. 29. $1060-1075$

Danquah, C., (2012). Determinants of Career Choice, Job Satisfaction and Retention of Academic Staff in Three Private Universities in Ghana: Masters' Thesis, Kwame Nkrumah University of Science and Technology.

DeVellis, R. F. (1991). Scale Development: Theory and Applications. Applied Social Research Methods Series, Vol. 26). Newbury Park, CA: Sage Publications.

Dokosi, E. D., (2014). Investigating the factors influencing career preference amongst prospective and recent graduates in Ghana: (Masters' Thesis), Ashesi University College.

Fabea, I. B., (2014). Factors that influence the career choices of students. International Journal of Research in Social Sciences. Vol. 4, No.2 ISSN 2307-227X

Germeijs, V. and Verschueren, K. (2006). High school students' career Decision-making process: Development and validation of the study choice task inventory. Journal of Career Assessment. 14 (4), 449-471 DOI: 


\section{$10.1177 / 1069072706286510$}

Ghana Education Service Register (2015). Retrieved from https://docplayer.net/16990657-Ghana-educationservice-register-of-programmes-and-courses-for-public-and-private-senior-high-schools-technical-andvocational-institutes-2015.html

Johnson, M. K. and Mortimer, J. T. (2002). Career Choice and Development from a Sociological Perspective. Career Choice and Development. 4, 37 -81

Kidd, L. M., (2006). Understanding career counselling; Theory, research and practice. London: Sage Publications.

Lawer, D.T. (2015). Factors that inform students' choice of study and career. Journal of Education and Practice, Vol.6, No.27, 2015

Mvungi, G., (2009). School-based factors influencing students' choices of teaching science as career: The case of government secondary schools in Ilala District: Unpublished M.A Dissertation, University of Dar es Salaam.

Otuei, C. O. (2017). Career decision-making difficulties of senior high school students in Koforidua Municipality. (Masters' Thesis): University of Cape Coast.

Puja, G. K., (2001). Moving against the grain; the expectations of Tanzanian female undergraduate students of University of Dar-es-Salaam. Unpublished PhD Thesis, University of Toronto

Stumpf, S. A., Colarelli S. M. \& Hartman K. (1983). Development of the career exploration survey (CES). Journal of Vocational Behavior. DOI: 10.1016/0001-8791(83)90028-3

Super, D. E. (1980). A life-span, life-space approach to career development. Journal of Vocational Behavior, 16 (30): 282-298.

Woasey, F. A., (2015). Factors influencing the career choice of undergraduate students in the humanities of the University of Ghana. (Masters' Thesis). University of Ghana, Legon.

Zotorvie, J. S. T., (2016). Determinants of Career Choice among Students of Institute of Chartered Accountants (Ghana). European Scientific Journal. 12(31) ISSN:1857 - 7881 (Print) e - ISSN 1857- 7431

Zunker, V. G. (1990). Career counselling: Applied concepts of life planning. California: Brooks/Cole Publishing Company. 